\title{
Carbonatites record recycling of the subducted ancient oceanic crust and overlying sedimentary carbonate
}

\author{
LI-QUN DAI*, WEI FANG, YONG-FEI ZHENG
}

${ }^{1}$ Chinese Academy of Sciences Key Laboratory of Crust-

Mantle Materials and Environments, University of

Science and Technology of China, Hefei, 230026, China

Carbon cycling in the subduction zone plays an important role in modulating Earth's atmosphere and climate. While carbon within the mantle may originate from recycling of crustal material by subduction, or it may be primitive and stored within the mantle. Thus, it is unclear whether the carbon liberated to the earth's surface could represent the recycled supracrustal carbon.

In this study, we present a combined study of whole-rock major-trace elements and $\mathrm{Sr}-\mathrm{Nd}-\mathrm{Hf}$ isotopes as well as carbonate $\mathrm{C}-\mathrm{O}$ isotopes for Cenozoic carbonatites from the Qinling orogen in central China. The studied carbonatites are enriched in LILE and LREE but relatively depleted in HFSE ( $\mathrm{Zr}, \mathrm{Hf}, \mathrm{Ti}$ ), with positive $\varepsilon_{\mathrm{Nd}}(\mathrm{t})$ values of 3.2 to 4.4 and $\varepsilon \mathrm{Hf}(\mathrm{t})$ values of 5.3 to 7.1 and significantly high $\left({ }^{87} \mathrm{Sr} /{ }^{86} \mathrm{Sr}\right)_{\mathrm{i}}$ ratios of 0.7080 to 0.7082 . They generally exhibit high $\delta^{18} \mathrm{O}$ values of 12.6 to $20.6 \%$ and variable $\delta^{13} \mathrm{C}$ values of -9.6 to $0.7 \%$. According to the significant difference in radiogenic $\mathrm{Sr}$ isotopes between the carbonatites and their spatially associated alkali basalts, we suggest they derived from different mantle sources but were not the result of liquid immiscibility or crystal fractionation. This inference is also supported by the significantly higher trace element contents of the alkali basalts than those of the carbonatites. The high $\mathrm{Sr}$ and $\mathrm{C}-\mathrm{O}$ isotopes of the carbonatites indicate that the subducting sedimentary carbonate was involved in their mantle source. In addition, the high concentrations of incompatiable elements and the significant enrichment in LILE and LREE suggest the basaltic oceanic crust-derived silicate melt was also required in generating their mantle source in addition to the sedimentary carbonate melt. Model calculations for trace elements further confirm that these carbonatites can be explained by the chemical reaction of the depleted MORB mantle peridotite with mixed melt derived from the subducting Palaeotethyan oceanic basalts and overlying sedimentary carbonate. Thus, the results provide new insights not only into the trace elements enrichment mechanism of the carbonatites, but also role of subducted acnient oceanic crust and overlying sedimentary carbonate in generating their mantle source. 